\title{
Alternation and Democratic Quality in Mexico: A Fuzzy Relationship
}

\author{
Fabiola Coutiño ${ }^{1, *}$, Alicia Hernández de Gante ${ }^{1}$, Angélica Mendieta Ramírez ${ }^{2}$ \\ ${ }^{1}$ Law School and Social Sciences, Meritorious Autonomous University of Puebla (BUAP), Mexico \\ ${ }^{2}$ School of Communication, Meritorious Autonomous University of Puebla (BUAP), Mexico
}

Copyright $(2017$ by authors, all rights reserved. Authors agree that this article remains permanently open access under the terms of the Creative Commons Attribution License 4.0 International License

\begin{abstract}
The democratization process initiated in 70's in Latin America was strengthened during 80's, which reveals difficulties across the political system. Political change, defined as change in succeeding parties, does not have the expected effects in the American continent as in European transitions, (O'Donnell and Schmitter: 1988). In the 70's and 80's, the continental countries-positively viewed by the Latin American countries-began their transition to democracy. However, over the years it was demonstrated that representative democracy does not necessarily imply democratic quality (Morlino: 2005) and the transition can have many outcomes. The question is: Why is democratic consolidation more complicated in a Latin American country? With respect to Mexico, after alternating in 2000, academic discussion has focused on the issue of democratic consolidation; however, electoral results in 2006 marked the turning point about the political direction. The increasing discontent, distrust and questioning to Federal Electoral Institute was demonstrated again in regular elections of 2012, where results were seen by many people as a setback. In consequence, the return of the Institutional Revolutionary Party has captured the attention of both political actors and scholars, and it has put into question the issue of democratic consolidation. So the main objective of this panel is to assemble a discussion from different perspectives about the Mexican transition, based, by one side, in the relationship between actors and institutions as agents of political change, and by the other, in the effects contrasted with the elements that determine the construction of a democracy of quality.
\end{abstract}

Keywords Delegitimation, Liberalization, Alternation, Democratic Quality, Citizen Dissatisfaction

\section{Introduction}

Considered to be the most efficient form of Government, democracy $^{1}$ [1] not only implies a set of rules of the game agreed previously by the political actors, but also creates conditions for the participation of citizens in the decision-making process, which influences the stability of a political system ${ }^{2}[2]$.

To do this, the rules of the game need to ensure uncertainty [3] with respect to the winner of the presidential race in a field in which citizen exercise their political rights fully; i.e., dice must not be loaded to favor certain competitors. However, for decades, in several countries institutional design favored the formation and strengthening of elite by resorting the gradual restriction of the rights and freedoms of its citizenship so that it could stay in power [4]. For example, through the control of electoral competition and economic incentives as compensation of political liberties in Brazil's authoritarian bureaucratic regime ${ }^{3}$; the simultaneous double vote and the strengthening of clientelism to the detriment of the rational vote in Uruguay; the persecution of leaders opposed to the regime and the prohibition of strikes in Peru, etc.

Such regimes were classified as authoritarian [5]. Thus, in the last third of the 20th century, the fact of much of the Latin American countries began their transition to democracy was seen with optimism. Nevertheless, with the passing of the years, it was demonstrated that

1 The democratic method was considered as institutional arrangement for the political decision-making that achieves the common good, making the people themselves to decide issues through the choice of individuals who must meet to execute his will. However difficulties were recognized to standardize opinions and desires, hence the consideration that the resulting political decisions of the democratic process are not the will of the people, because the information is handled, and even though the selective information is correct try to lie telling the truth; It does not deceive the people on a permanent basis, which ends up confirming that in fact does not participate effectively in the decision-making process.

2 The events that occurred during and after the Second World War, confronted two paradigms on the issue of participation: democracy and authoritarianism, in which the first occupied an important place by giving citizens the opportunity to participate freely in public matters and in the decision-making process. Hence schools aimed at the study of political behavior and public opinion arose, such as the behavioral, where he coined the concept of political culture, used to explain the stable democracies.

3 Among other issues, during the military regime, direct elections for the Presidency were suppressed and the Contrarianism as an expression of political patronage 
representative democracy does not imply itself [6] democratic quality, which is related to the type of political system.

In this regard, when specialists from various disciplines analyzed Latin American democratic regimes, they began to bet more on European transitions than on the American continent because they understood that there were obstacles in common for the consolidation of democracy in our countries; among them, the continuity of the coups, constitutions, the difficulty to achieve political agreements, the lack of effective representation and the type of political culture, all aspects related to the political system.

Some situations that reflect the problems revolving around democratic consolidation are, for example, the case of Venezuela, in which elections Maduro was imposed in power ${ }^{4}$ despite of the lack of results by the opposition ${ }^{5}$; Mexico, for its part, because the subsequent presidential elections of 2006 showed the crisis of legitimacy ${ }^{6}$ beginning of the administration of President Calderon, which deepened when implementing its policy of war against drug trafficking, and the second alternation that happened in 2012 was preceded by students' protests $^{7}$ in most of the states, same that started on May 11 in the center of the country and they spread throughout the national territory during the following months. The most critical phase of such protests was from the Election Day until months after the elections were counted, as a result of the rejection of the results.

Another case is that of Honduras, which, despite being a democratic regime, in 2009, was not saved from the bad experience of another coup that marred its democratic transition. Thus, such Latin American experiences explain the need to analyze the Mexican case. In order to do this analysis, we will begin by addressing the main concepts of this subject widely discussed in the social sciences.

\footnotetext{
${ }^{4}$ At the end of the 90's, countries like Venezuela raised the failure of traditional political parties, as opposed to the leftist movements; however today the Venezuelan political system crosses a crisis of legitimacy, because the proposal to reform the Constitution to establish the indefinite presidential reelection questioned trial Chavez of the Socialism of the $21 \mathrm{st}$ century project.

5 Maduro has performed the charge of President, despite the ignorance of them results by his opponent, Henrique Capriles, which produced great concern to the raise is the possibility of a coup of State. Years before, results of the elections on Sunday, February 15, 2009 in Venezuela, were clear at the time that the triumph of Hugo Chávez, implied a change in the rules of the political game. Venezuela is now in deplorable conditions that reveal even that food security is at risk.

6 The choice of 2006 recalled to many Mexican the Cyber fraud implemented by the PRI in 1988. This put into question the political reforms of 90,93 and 95, after which came the alternation in 2000, thus not ensured continuity in the democratic development.

7 The \#YoSoy132 as a social movement started in the

Iberoamerican University, just when Enrique Peña Nieto presented himself as a candidate for President of the Republic, to participate in a forum organized by that University. During his presentation the students questioned the repression he exerted against some merchants when Peña Nieto was Governor of the State of Mexico, the treatment that the students received from the leaders of the PRI, led to the organization of a large number of protests, among them the demand for the democratization of the media that clearly favored the candidate of the PRI.
}

\section{Frame of Reference}

The efficiency of a democratic regime implies that politics determine the activity of the State, provided that active citizens participate in public life. In relation to the aforementioned, there are different approaches on the political system, but, undoubtedly, it is a priority to consider that it is defined as a set of interactions that produce decisions exercised by authorities, which are explained by their inputs and outputs ${ }^{8}$ [7]. The systemic approach $^{9}$ [8] has been useful to explain the political phenomenon; however, there are others, like the institutionalist one, which links patterns of behavior with the type of institutions ${ }^{10}$ [9]; and the sociocentric on, which depends on the role of society in relation to the stability of the political system ${ }^{11}$, among others. In this case, we are interested in using the systemic approach, which is appropriate for the analysis of the variables that we are interested in, on the understanding that two basic components of the political system are the electoral system and the system of parties ${ }^{12}$ [10].

The electoral system, in fact, as we understand it in its wider sense, is not only referred to the procedures that are used to convert votes into seats, but its content is made up of a set of elements that span both institutions and the relationships between the actors [11]. The electoral system in each country produces different effects, so that institutional design influences the type of results, as well as the conditions of competition for power or the rules of the game. Some positions list political systems with the framework of the institutional political system [7], by considering that political relations are characterized by targeted towards the legitimate and authoritative allocation of values in a society.

This is why politics are immersed only within the network of relations of power, which is a distinctive trait of

8 Easton developed a theoretical model to explain the variety of expressions which has the political life of a community, meaning the authoritarian values distribution policy structural-functionalist, the author of Approaches to political theory writes that the Second World War marked a turning point in the history of political science.

9 On a conventional definition, a system is a set of elements interconnected among themselves, although this was in fact a theoretical proposal of Bertalanffy coined in biology. Luhmann raised the existence of social systems whose functions are very similar to the biological, inorganic and personal systems. Thus, as part of a social system to highlight the economic, political, and legal subsystems which in turn become systems against other sets of relations.

10 Hall and Taylor emphasize, on the one hand, the development of the institutionalism historic; the rational choice, and the sociological in perspective comparative, in each case, the system political plays an important role.

11 Almond and Verba indicate the relationship that keeps the stability or instability of a political system with the kind of political culture, hence the influence of quantitative studies oriented towards the behavior and public opinion.

12 Political party in Sartori is any political group that arises to elections and that can clearly place through elections their candidates in public office. On political systems, there are two major divisions proposed by Duverger, democratic systems, which in turn are subdivided in parliamentary systems and presidential systems, and authoritarian systems, subdivided into dictatorial and sultanistic. The classification is determined by the freedom that the individual has to participate in the decision-making process, if this is limited we are facing an authoritarian political system. 
an institutional political system, which is the only one to perform this type of assignments ${ }^{13}$. This highlights the importance of previous agreements in a political constitution. However, we should also consider the effect that social movements have since, although they are formally recognized outside the structure of the institutional system, they have a strong influence in the decision-making process.

In this way, we observe that electoral systems are a parameter to identify the level of democratic State that is studied. This is the reason why it is necessary to deepen its analysis, because each day it acquires a major interest in political representation, political communication, gender quotas, electoral institutions, electoral geography, electoral processes and the improvement of electoral bodies' competition for power, political actors and other factors that are the subject of study of different disciplines. Democracy and electoral processes entail a relationship that affects the legitimacy of ruling through a previously established set of regulations, and they also have a close relationship with the political system, which is the topic that we will talk about next.

\section{Political System and Democracy in Mexico}

The support of liberal democracy is the recognition of the universal, free, secret and direct suffrage, which determines the participation of citizens who contribute to the renewal of the political power in a State.

In the Mexican case, it is necessary to remember that the movement began with the Mexican Revolution in 1910. The reason for this movement was the violation of the electoral rules, which aimed at the renewal of political power since Porfirio Díaz had been in power for more than thirty years in power. Madero, who won the first democratic elections after the Revolution, launched in 1911 the Electoral law that established for good some of the most important electoral institutions of the Mexican political system, including the recognition of political parties, the registration of candidates, and the presence of party representatives in the electoral bodies and some bases of political competition, situation that led to the creation of a large number of parties, which, even by the revolutionary context, arose under the protection of warlords [12].

This scenario is the prelude to the construction of the Mexican political system, since the revolutionary movement, besides having achieved the incorporation of social rights in the Constitution, changed the rules of the game by limiting the position of the Federal Executive to only four years ${ }^{14}$. At the end of the 1920's, there were

13 Identification of policy with the institutional political system is disputed (by the secrecy of its borders of analysis) to the complexity and social dynamics and by the importance and influence of the action.

14 On 24 January 1928 article 83 Constitution was amended to set the six-year period for the position of President of the Republic, which was around 2000 political parties, which were actually scattered forces in various regions of the country, the majority of local character, dependent or military warlords and chieftains. Thus the PNR was born, bringing together those political forces, parties or popular organizations, military leaders headed by a national Executive Committee through which the authority of streets was imposed ${ }^{15}$.

Considering the above, it is not possible to speak of the Mexican political system without referring to the institutional Revolutionary Party (PRI). In order to address the issue of the electoral system and the party system it is essential to bear in mind the influence of this party, on the one hand, in the organization of electoral processes, and on the other, in a hegemonic party system of long-term peacebuilding.

\subsection{Mexican Electoral System}

The electoral system is a subsystem of the political system, which influences, on the one hand, the political will, and on the other, the settings in the renewal of the public authorities [11]. The elements that make up the electoral systems are gradually transformed because of the social and political changes.

An important part of the entire electoral system is regulations, since the renewal of the representatives is carried out according to constitutional precepts representing political and legal decisions previously agreed, giving existence to the electoral law, which first source is the Constitution containing the political rights and obligations of citizens [13].

In the same way, the fundamental norm establishes the basis for the renewal of the public authorities, the competition of political parties, electoral institutions and the organization of elections; the Court that resolves resources and procedures by political parties; as well as the principles governing the Organization of the elections in the federal entities, are all contained in articles 41, 99, and 116 of the Political Constitution of the United States of Mexico, respectively.

From the fundamental standard arise regulatory laws that govern all aspects related to the Organization of elections in Mexico. Such is the case of the political and electoral reform of 1990, which established the creation of an Institute responsible for organizing elections, and of the Federal Code of electoral institutions and procedures (COFIPE).

The last electoral political reform was in $2014^{16}$, as a

previously four years.

15 Fundraising which was agreed that all the bureaucrats give into one day's salary for each month to bring 31 days, 7 in total. Already this experience had been put into practice Emilio Portes Gil in Tamaulipas. All these resources channeled toward the party allowed him to create the bureaucratic apparatus necessary to cope with their opponents.

16 Reform is to be tested on December 11,2014 by the Chamber of Deputies with 351 votes for, 86 against and 4 abstentions. During the session, the convergence of work parties, new partnership and alternative strongly criticized the approval and showed that the agreements, previously had moored. The reform was published on February 22 of that year. 
result of the discontent generated in ordinary elections in 2012, which has been characteristic of this country since 1988. After each presidential election, there is an electoral reform as a result of the dissatisfaction arisen from electoral results ${ }^{17}$. Coupled with this are the agreements of the administrative authorities, as both local and federal electoral legislation empower the electoral authorities to resolve procedures, agreements of collaboration with federal, State and municipal authorities, etc., and on the other hand, the jurisprudence on electoral matters, consisting of the legally binding criteria arising out of the interpretation made by the jurisdictional authorities over a legal dispute. It is important to emphasize the character dynamic of electoral reform in Mexico because each administration implies policy changes, usually associated with the struggle of the opposition parties, because in rare cases, these have been the ruling elite decision ${ }^{18}$ [14].

We will now refer to another factor that has been instrumental in the transition to democracy in Mexico.

\subsubsection{Mexican Electoral Institutions}

Since the beginning of the 20th century to the present day they are distinguished three sets of electoral institutions in our country; the first part of the institutionalization of them parties in Mexico, i.e., from 1911 until 1945, period in which is perceived certain improvement in the integration of them organs electoral to the not exist presence of any of them powers public in it structure institutional electoral, which not had character permanent but temporary. It organization election was in hands of them municipalities, responsible of all the activities relating to the electoral ballot, nominal lists, appointment of candidates, installers of boxes, integration of tables of box, leaving in this case, the qualification of them elections in hands of the legislative, despite this them elections were violent. On the subject Bulnes said would not succeed in Mexico the presidential candidate who does not have bayonets and official support? [15] the electoral law existed, but almost nobody was based on it.

However, the next period began with the political reform of article 46, consequence of the strategic innovation of the Party of the Mexican Revolution (PRM), which until then consisted of four sectors or corporate lines (workers, peasants, military and popular sector); in this way became the PRI ${ }^{19}$ and this determined the new leadership of the party: now the important thing was to ensure political

17 The exception to the case occurred with the alternation in the year 2000, when a panist arrived for the first time to the Presidency of the Republic, because the following electoral reform derived from the rejection of the results of the 2006 elections was in 2007.

18 Woldenberg proposes a periodization relating to electoral reforms, thus considered that in a first phase, changes were preventive, for example in 1977 and 1986, when reforms driven by the Federal Executive, in contrast 90-91, 93-94 and 95-96 were result of pacts between the PRI and some opposition parties.

19 In El Universal newspaper, 19 January 1946 appeared the next header in front-page: party of the revolution died yesterday with the national approval. Corresponded to Antonio Villalobos in his character of President of the II Assembly national of the PRM make the Declaration of that this disappeared, and of that was constituted the PRI (...) stability and economic development of the country. The reform formally joined the executive powers and legislative organs within; since then and until 50 years later, the electoral organization was carried out with the absolute control of the Executive Branch and the Legislative Branch participation. During that time, the Secretary of the Interior was the head of the body responsible for organizing the elections, which was extremely disadvantageous for the opposition parties, because this mechanism controlled political competition.

In fact, the political system revolved around an overwhelming centralism and although the word democracy was common in speech (starting from the own theme party democracy and Social Justice), reality showed the opposite: the President prevented the division of powers, opposition parties were more formal than real, electoral bodies were fully controlled, because to begin with were presided over by the representative of the Federal Executive.

The third period began in 1990 and coincides with the creation of the Federal Electoral Institute (IFE), six years after political reform ended with half a century of PRI control to eliminate definitively the representative of the Executive power in the integration of electoral bodies. This normative framework agreed without all the political actors determined that in the 1997 interim elections the PRI lost the majority in the integration of the Federal Chamber of Deputies $^{20}$, similarly, the effect it had at the local level was that for the first time the Government Headquarters of the Federal District was in the hands of another party, Engineer Cuauhtémoc Cárdenas, from the Party of the Democratic Revolution (PRD) ${ }^{21}$. This election was the prelude to the political alternation in the Presidency of the Republic in the year 2000, whose elections were characterized by high competitiveness. The political marketing strategies used by Vicente Fox's campaign team earned him the victory by reaching the majority of votes.

It is worth to point out that, contrary to expectations, 2014 reform ended up becoming the currency of the energy reform, and although not entails profound transformations aimed to improve procedural democracy, contains attractive aspects that are now on the table for discussion, that is, started by the adoption of a new name of institutions in charge of organizing the elections both at the federal level, as in the entities, as well as its restructuring, in addition to this, incorporated new rules of the game for competitors, among which stand out, as issues,

20 For example, the National Action Party (PAN), the main opposition party to the PRI, decided to withdraw from the negotiating table where the content of the political-electoral reform was deliberated, so the agreements were made between the PRI, the Party of the Democratic Revolution (PRD) and the Labor Party (PT). These were known as the Bucareli Agreements.

21 Cuauhtémoc Cárdenas is one of the great leaders of the Mexican left. In March 1987 he was expelled from the PRI, which was appropriate to contend the following year as a candidate of the National Democratic Front. In those elections the legitimacy of the triumph of PRI member Carlos Salinas de Gortari was profoundly questioned, favored by the National Electoral Commission headed by the Secretary of the Interior Manuel Bartlett Díaz. 
independent candidates and nomination.

Here we should highlight the theme of the new powers of the Electoral Institute, organism that supplemented only in name, the IFE, since the Organization in a federal system determines that in Mexico there are, since 1946, two types of election officials o, responsible for federal elections and State election agencies, whose main function is the election organization concerning the renewal of representatives of executive powers Legislative, and integration of local councils in their territorial boundaries ${ }^{22}$.

However, the reform was created organisms public electoral local (OPLES), which replace the electoral institutes of the States, who today share tasks with INE in the federal organization of the elections of the entities, which is novel in Mexico.

Furthermore, the restructuring of INE was one of the most important areas in the Organization of the elections, the National Electoral professional service ${ }^{23}$, which is selection, admission, training, professionalization, promotion, assessment, rotation, permanence and discipline of public servants of the Executive and technical INE bodies and, now, local federal entities public bodies. Similarly there are courts, federal and local; which resolve the appeals by the parties and their candidates.

The reform, for the purposes of an electoral chord and economic organization, synchronized electoral calendars, so that ordinary elections for 2018 both the Executive and legislative branches federal, as the State, as well as the integration of city councils and boards auxiliary, renewed if it were the case, the latter with the intention that the Governors of the States did not have the ability to manipulate the decisions taken by the bodies of State institutes election, pledging some results ${ }^{24}$.

\subsubsection{Political Representation}

As noted earlier, from 1946 to 1990, important changes in the political system took place. The constitutional reform of 1977 created the multi-member constituencies ${ }^{25}$. At that time the Federal Electoral Commission determined the number and territorial scope of the constituencies, which initially were three, then were increased to four, and from 1986 until now there are five, whose composition has been changed gradually. As prior to each electoral process,

22 In some cases, for example in the State of Tlaxcala, the Electoral Institute organises, in addition, the elections of the auxiliary boards, whose function is to support the tasks of the local councils in the municipalities.

23 Before it was Professional Electoral Service, integrated by professional career staff, and was created as the Directorate of the IFE in the political-electoral reform of 1992. A National Professional Electoral Service is currently being integrated, derived from the 2014 reform.

24 In Puebla, Guerrero, Veracruz, Oaxaca and other subnational democracies has been obvious the influence of the Governor at the Electoral Institute, both in the integration of the electoral management body and decisions taken in the steering mechanism, but this measure did not change the influence exerted in the Executive branch of a State electoral processes.

25 The multi-member constituencies are the areas in which is divided the country for the distribution of charges obtained by the principle of proportional representation. Currently in each plurinominal constituency 40 members by the principle of proportional representation are chosen. it is now the General Council of the IFE or the governing body of a local Institute the one who decides the redistricting; however, in some states it is usually gerrymandering ${ }^{26}[11]$ because this has been an advantage for the ruling party, so changes in geography electoral precursors to process election are due to the convenience of the political elite. In terms of representation, for a long period the PRI, once positioned as the axis of the Mexican political system in 1946, carried out an over-representation and, therefore, the difficulty for alternation in political power.

Hybridization between State Organization and official party whose head of the Executive was the head of both, were the best advantages for the PRI, in addition to this, the control of the organizing institution of the elections determined that up to the electoral reform of 1963, with the idea of changing the authoritarian image, created the figure of members of Parliament, in order to facilitate the representation of opposition parties. In the next federal election on July 5,1964 , bread, obtained 20 party members; 9 the PPS, nine; the PARM, 5; that means 32 in total, which represented $15.3 \%$ of the camera, which was a very important step for Mexican democracy.

Unfortunately, the repressive character of the political system during 1968, dominated by the PRI, resulted in massacre of Tlatelolco. This bad experience for Mexican society was reflected in the increase in demonstrations at the beginning of the 1970's, and also in the polls, because the turnout was very high in the 1970 presidential election. As well in the following presidential process, in 1976, PRI the candidate was the only candidate, who, despite all, conducted an intense campaign [16].

Already then, the elite had clear the need of legitimize. Hence, in 1977, with the inspiration of Jesus Reyes Heroles, then Secretary of Governorate, by first time is heard to them parties of opposition for develop the reform political and electoral, of this way, is incorporated it representation proportional through the creation of 100 multi-member members, and it also recognized them as national political associations. This expanded the participation of political parties within electoral organs, allowing, even to those parties with record conditioned participate, the same with right of voice. Access to the media was regulated and established themselves as prerogatives of political parties public funding.

However, the López Portillo Administration ended much challenged by the devaluation of the Mexican peso, so the new President, Miguel de la Madrid, prompted another constitutional amendment to extend the spaces of representation. Since then, the Chamber of Deputies, in addition to the 300 members of relative majority, has to win 200 members of proportional representation, although the topic of the discussion has focused on the need for this

26 Consisting the adaptation of the constituencies to promote the vote for a political party, seriously affects the fairness of the election results. The accommodation of the constituencies is given from the electoral reforms, generally aimed at the benefit of a party. 
type of representatives half.

Here it should be noted that the last reform provides for consecutive re-election as legislative representatives, and members of city councils; thus, the Senators may be elected up to 2 consecutive terms and the members of the Congress of the Union up to 4 consecutive periods.

There is a padlock, because the application only may be made by the same party or by any of the parties' members of the coalition that they have postulated, unless have waived or lost its militancy.

Re-election at the municipal level applicable for the same office of mayors, aldermen and Trustees, for an additional period, when councils' period does not exceed three years; but again, we have another lock because the application can only be made by the same party or any of the Coalition, which integrated the same except that in the former case. The same applies to the local members.

Returning to the stage that contextualizes the background of the first alternation in the Federal Executive, after the period of liberalization reforms that gave guideline to a fairer electoral competition, the 1988 election-driven where the Federal Electoral Commission declared the triumph of Salinas with the $50.36 \%$ votes against the $31.12 \%$ of votes of the national democratic front and the 17.07 percent of votes obtained by the PAN.

Again, this election showed authoritarian control exercised by the PRI on election results, being one of fraud evident in Mexican elections. Salinas only legitimized their power during the exercise of their duties, but citizens remember these elections, along with 2006, as the most fallacious ones. However the importance of this election is focused on the rise of an initially solid left in the country.

Another reform was required, but different from the previous ones, and the strategy it was create the IFE, though in their first years of life continued leading the PRI the steering mechanism, so that the opposition was dissatisfied and full fight for the democratization of the organizing institutions of the elections.

Without the presence of the party of the Democratic Revolution (PRD), the reform of 1994 was negotiated with other parties and it governance clause was eliminated ${ }^{27}$ [17], removed the self-qualification of Deputies, senators and Assembly members, however, the TFE continued grading the election presidential and even when a second instance of the TFE was created, with the intervention of the Federal Judicial power, these would continue subject to the President of the TFE which enjoyed broad powers, legislated on public and private financing, access to the media; but its disadvantages include (art. 54 constitutional) locks that prevent the consistent political representation

27 The party which won more districts making 251 or more members is you would give two additional seats for every percentage point that was over $35 \%$ to less than $60 \%$, which was based on the article 54 of the Constitution. This formula reflected the clear intention of the PRI to be sure where the index from its vote decreased as in the 1988 federal election, but did not take place as well, and as a result governance clause was not applied in the following election. It was approved during the administration of the President Miguel De la Madrid Hurtado. with the votes obtained by political parties, were locks to form coalitions and thus prevent what happened in 88 when an important opposition front; complied but let's not forget that this reform was eliminating the PRD.

Although it was stated that the elections of the 94 would be the most hotly contested and transparent, the truth is that participated 9 candidates, including Luis Donaldo Colosio, postulated by the PRI, who was brutally killed. The PRI named Ernesto Zedillo as candidate, and surprisingly, it was one of the elections with broader participation in Mexico. Zedillo promoted the definite reform, widely criticized by its name, but with significant contribution to unlink to the Secretary of the Interior, it was the stage of the improvement undertaken since 1994. With regard to political representation, it was agreed to decrease the maximum number of members from a political party by the principles of plurality and proportional representation. The principle of proportional representation was also included in the integration of the Senate.

This implied a condition of greater balance in the composition of the legislative branch in Mexico, as it was established that a political party could not have more than 300 members by both principles. In the Chamber of Deputies, proportional representation was limited to pointing out that the councils by this principle that deducted after assigning the corresponding to the political party that exceeded the legal limits would claim other parties with right to do so in each one of the multi-member constituencies.

With regard to the Senate, it is composed of 128 senators, two elected by relative majority and one assigned to the first minority, in each State and in the Federal District, respectively. The remaining 32 Senators are elected according to the principle of proportional representation, by using the system of lists voted on a single national plurinominal constituency.

With these rules of the game that included the disappearance of the Executive in the reform to the federal electoral act in the 1996, the PRI lost its majority in the mid-term election of 1997. Since then then, the President has to negotiate with the opposition, which marks a very important difference with other periods. But then the alternation in the Presidential Office came. However, regarding the representation policy, there is much left to solve in terms of effectiveness, as we still fail to ensure the representation of the minorities, and even mechanisms such as the gender quota have been insufficient to ensure the occupation of spaces of power.

\subsubsection{Competition for Power and Political Communication: Parameters for the Possibility of Alternate Political Power}

The rules relating to competition for power are contained in various jurisdictions: the Federal constitutions and local; the electoral laws that govern both levels; the General Law of electoral offences, in the part concerning the electoral sanctions; the regulation in the field of Radio 
and Television ${ }^{28}$; the agreements and resolutions of jurisdictional and administrative authorities among others.

Electoral reform, moreover, created new punishable subjects: citizens, dealers and licensees of the means of communication, business and trade union organizations, etc., and also toughened sanctions. The reform led to a complicated relationship between Televisa and TV Azteca, political parties and the organizing institution of the federal elections, situation that has affected citizens' perceptions.

\subsection{The System of the First Alternation in the Executive Power of the States and Parties}

The party system understood on the basis of relationships arising from the competition of these political organizations involves not only their quantity, but the structure; changes in its interior, division and ideological polarization; type of orientation, as well as their chances of victory in the political strife [18]. In this context, the election results are an indicator of the importance that each party has within the system. In terms of competitiveness, it is possible in contexts of pluralism, tolerance and freedom if there are conditions attributable to that any of the contenders can win in the election, which is a fact related to democracy [3].

The number or parties, level of competitiveness and proportionality-disproportionality are factors that determine the conformation of local legislatures. So for a long period of time, the system of parties in Mexico was multi-party, but non-competitive ${ }^{29}$. As noted above, the advantage that the PRI had helped it to control the electoral organization in order to insert itself into the governing body of the organizing institution of the elections from 1946 until 1996. This led to the impossibility for another party to win elections. However, at the end of the $80 \mathrm{~s}$, opposition triumphed in some States; for example, the PAN in 1989 wins the governorship of Baja California; in 1991, the governorship of Guanajuato and in 1992 that of Chihuahua; in 1996 that of Guanajuato ${ }^{30}$.

The electoral reforms carried out from 1990 to 1996 they favored short-term alternation in the Presidency of the

28 It electoral reform of 2007-2008 incorporated a new model of communication, existing until today, was a part waters concerning the use of them resources of them parties in their campaigns, as the inclusion of the subsection 1) of the article 118 of it legislation regulatory provoked the anger of them two television stations of greater relevance in the country, since this precept sets as attribution of the Council General of the IFE, the of monitor permanently that the Institute exercise their powers as authority only in the administration of the time that corresponds to the State in matter of radio and television intended to their own purposes. Despite the struggle to regain the discretion with respect to the use of time in radio and television, arguing, even the violation of guarantees, the regulation of Radio and Television in electoral matters the General Executive Board submitted to the General Council for consideration, was approved.

29 Sartori named the hegemonic Party PRI not fit this in any of the classic types, dominant or predominant party, bipartisanship, multi-party system, since the latter occurs when two or more parties have the ability of coalition.

30 Vicente Fox Triumphed as candidate to Governor of Guanajuato 4 years before being elected first President of the Republic of the opposition.
Republic, to create conditions for the competitiveness of the party, which was reflected in the 1997 mid-term election, to change the configuration of the legislative branch in Mexico, with whom he since then, the President of the Republic, must agree ${ }^{31}$, which has been extremely difficult given the absence of a tradition to negotiate among political actors.

As well, in addition to the aforementioned States, the triumphs of the PAN reach Nuevo Leon and Queretaro in 1997, Aguascalientes in 1998; Morelos in 2000; Yucatan in 2001; San Luis Potosí in 2003; Tlaxcala in 2005. Similarly, the PRD won the Executive in 1997 in the Federal District, with Cuauhtémoc Cárdenas as the first city mayor elected democratically $^{32}$; in 1998 in Zacatecas; that same year triumphed in Tlaxcala, in 1999 in Baja California; in 2001 in Michoacán; in 2004 in Zacatecas; in 2005 in low California South and Guerrero, and so on. In consequence, today there are only 9 states in which there has not been political alternation: Campeche, Coahuila, Colima, Durango, Hidalgo, State of Mexico, Quintana Roo, Tamaulipas and Veracruz.

And, as the structuring of those parties political depends of the type of regime, in a presidential system the Executive Branch becomes the main objective, both at the federal level, as in the State, so it is no coincidence that in the American case parties are atypical [10], i.e. electoral machines, but parties in Mexico, have a different story to the other countries. It suffices to recall that the PRI was the axis of the Mexican political system for five decades, although it was not a party, as any, but the PRI-Government [19], which influenced that the opposition had as the basis for weakly institutionalized organizations.

However, even after the alternation in 2000, parties maintain a weak structure and elite divided that affects the lack of identity with a party. As the old PRI, anti-democratic political practices are current in the life internal of them parties, due, not to the lack of regulation, but to the poor application of the law $^{33}$.

31 In that election the PRI only obtained 36 percent of the vote, the PRD won $25 \%$, but by adding percentages of opposition parties, they outperformed the official party, and lost the chance to continue the majority party in Congress, which placed him on the need to negotiate each initiative.

32 The last reform, this year, transformed the city of Mexico Federal District.

33 The reform of 2014 multiplied the number of laws linked to the processes of renewal of the political power, effect, today we have 14 laws, including that of political parties, because in Mexico did not exist before a specific regulation for political organizations, when much of the countries decades ago, already had this type of legislation, for example, Spain , in whereas product of the law for political reform in 1976, from December 1978 was published the law of political parties with effect in strengthening its system of parties because, thanks to her could resurface the Communist Party Spanish (PCE), which represented the opposition to Francoism; in Uruguay, prior to the election of public officials, electoral bodies control the internal party election to make the designation of candidates democratic; Venezuela partisan activities are regulated by the law of political parties, public meetings and demonstrations and in Chile, the constitutional organic law of the political parties and in Ecuador of political parties law is valid number 2262, among many other cases, but the law of parties of Mexico, having already had two processes application, shows that the standard is insufficient to ensure that the behavior of the actors fits her. 
Certainly, the existence of legislation that regulates the inner life of parties would not imply that by that fact only be resolved disputes arising between the militants and the dome. However, there is no doubt that it would create conditions for democratizing these political organizations gradually because, although the Federal constitutions and local state otherwise ${ }^{34}$, it occurs that these political organizations are far from being democratic.

In addition, there are anti-democratic practices that turn militants of the parties during an electoral process. The reason is that the PRI, during its long period of hegemony, despite always have control of the entire election organization, resorted to Alchemy [20] in order to add votes and remove take votes away from the opposition. This was done by the purchase of voting, coercion of voters, and use of the public budget, which are all illegal behaviors used to out-perform the contenders which have been reproduced by the parties that previously denounced the PRI.

Also, it is important to note that the electoral reform of 2014 returned to them nominations independent, figure received with very high expectations, because the speech official highlighted them benefits that would imply for it Mexican democracy, between them, the increase of the participation electoral, the strengthening of it credibility and trust citizens, the warranty of a competition more equitable between them contenders in a choice the extension of political rights, democratic progress and other aspects, although two of the most debated issues which derived precisely from its first participation in the electoral arena in 2015 was, on the one hand, the character of independence of candidates and, secondly, regulatory deployed on standards lavishly favoring to political parties, to the detriment of the scarce possibilities of triumph by effect of the same rules of the game, they have the first.

\subsubsection{Alternation and Democratic Quality in the Mexican Transition}

Once emerged them theories of the change political, Mexico, in comparison with countries that had a long tradition of Governments democratic happened by hits of State [21], never had elections interrupted, because the relay of the power was continuous, however, the permanence of a party political (PNR and its transformations in PRM and PRI), in the power by more than eighty years He led that it was classified as hegemonic party [18], until in 2000, the National Action Party (PAN) became, for the first time, the Presidency of the Republic ${ }^{35}$, aspect that opened the possibility to also achieve the alternation in the federative entities.

\subsubsection{Alternation and Democracy's Quality}

Alternation and quality of democracy do not necessarily

34 Express regulations that must be inside democratic organizations and contribute to the development of a democratic political culture.

35 From 1989 to 1999, before the alternation in the Executive federal, ruled the opposition in 11 entities; in 6 States, the PAN; and in 4, the PRD. go hand in hand [6], as focus democratic quality is part of the contemporary debate, mostly because once the procedural democracy speech, fell to the account of the feasible which is hosting through various resources, aspects that tarnish the electoral process affecting the fairness of the political strife and the principles of democracy, through legislation according to the interests of the ruling party; but also when there is subrepresentation; a hegemonic party, or them as common practices, anti-democrats prone to happen in each election, which relates not only to militants, supporters and candidates of them parties to the seek is advantages facing their contenders, but, to its own citizenship heiress of behaviors illegal that is reproduce process after process.

The quality of democracy implies a regime widely legitimized, stable, and oriented to satisfy the social demands; where freedom and equality are attributes people in its expression. It implies that power is controlled and evaluated through institutional channels, which has an impact on increasing the spaces of participation.

To identify the level of democratic quality of a political community, stories such as the rule of law, accountability, responsiveness to citizens' demands, respect for rights and freedoms, and gradual expansion of political equality, social and economic were discussed.

This emphasizes the importance of a legal framework aimed at such purposes, which must be made known to the citizens and also observed by the authority.

For this reason, alternation is a small step in the process of democratization of the regime, but does not necessarily guarantee quality of democracy, especially if the new Government retains the same practices that limit the development of democratic, as in the Mexican case.

If we consider the five elements of an ideal democratic process: equality in voting, enlightened understanding, effective participation, final control over the program, and inclusion [22], this reflects the long missing tour in Mexico. Certainly, we have to recognize elections in 1997 to propose a new scenario with overtones of partisan competition, because the PRI lost the absolute majority in the Congress of the Union, which led to the positioning of the PAN and the PRD as protagonists in juxtaposed and divided Governments, but the influence that can exercise citizenship in the process of decision-making is still absent precisely because in Mexico it has intensely promoted an electoral democracy, but not the democratic quality.

Outside electoral participation, the instruments of direct democracy remain only in some constitutions and regulations, but are not part of the daily political life, as they should be, and although the last electoral reform included the quality of democracy, In turn, it is based on a democratic political culture characterized by the public trust $^{36}$; tolerance; and the ability of the political elite to

36 Trust is based on individual perceptions, that move to act in certain way to an uncertain situation. It that trust, not necessarily receive reciprocity in the sense of view reflected expectations that previously took in the depositary of their confidence, hence the fragility of this attribute. 
establish commitments and consensus [23]. In each one of these aspects there is a long way ahead.

Another problem that must resolve the democratic model is the satisfaction of social demands, as representative democracy is inadequate when it coexists with a deep social inequality. Therefore, now we should consider the existence of democracies in quality or good democracies and democracies without quality. The first involve largely legitimate and stable regimes that meet their society, not just a part of it, and its citizenship exercises conditions of freedom and equality above the minimum, considering, in addition, the ability to monitor and assess government performance.

The difficulty of any democratic transition revolves around it, as the degree of quality of a democracy would be defined by: respect for the law, accountability or Government accountability, responsiveness or reciprocity, which implies responsiveness that defines satisfaction citizen, full respect for the rights that are expanded on the realization of freedom, and, progressive extension of political, social and economic equity [6].

However, Mexico continues favoring the moment that citizens expressed their will to choose, but leaving aside their active participation, once defined the political representation, which implies a sort of complicity that relates both to the institutions, as the citizens, given the comfort that is the only fact vote, as the responsibility for the representatives. Although the 2014 reform also established public inquiry, in reality that figure locks proper participation, so it would be extremely difficult to achieve the required percentage that have effect on the decision-making process.

Accordingly, transformations on electoral matters in the last two decades have been directed to the strengthening of representative democracy through the creation of professional institutions in their roles and the modernization of the electoral laws, which, in theory, intended to make fairer competition between political forces. However, they led to conditions for the alternation in the Executive of the States and the Presidency of the Republic in 2006 and 2012; but the behavior of political actors gives an account of the difficulty which involves eradicating most of the behaviors associated with fraud, instead of to the quality of democracy. At the same time, the electoral reforms were tied with others that further social benefits, which have affected the impoverishment of the country ${ }^{37}$.

Thus, although the alternation in 2000 inspired hopes of Mexicans, the economic policy implemented by the PAN administration, the increased insecurity, drug trafficking, unemployment and social violence, coupled with the embarrassing experience of the elections of 2006, put into

37 In 1993 was amended article 133 so that international treaties were Supreme law. The signature of the NAFTA, involved the neglect of sectors strategic to compete in the market accordingly, the 1 of January of 1994 is rose the EZLN and, shortly after, the society Mexican was victim of the error of December. question our democratic level. Thus, the lack of citizen satisfaction, faint-hearted agreements of the political elite, and the poor implementation of laws reflect what we still need to achieve democratically.

But this is not that different in other countries. There is much more left to do about social democracy and, unfortunately, the political elite is still more interested in the strengthening of electoral democracy, for the sake of legitimacy, that in designing institutional mechanisms aimed to gradually reduce social inequality. Thus, although many Latin American countries began its democratic transition since the $1970{ }^{3} \mathrm{~s}^{38}$ [21], their political system has not created conditions to solve most of the problems afflicting their societies, which makes them vulnerable to the social pressure that could trigger a coup, although it is not the case of Mexico.

In this regard, the fundamental contradiction at the heart of liberal democracies has been established by political equality favoring the privileges of the political and economic elites, at the cost of fathering economic inequality progressively, which tends to restore a new aristocracy based on capitalist property, as Duverger states. But when the representation has lost its sense and the exercise of public office ends up forgetting the interests of their constituents, then legitimacy is weakened.

The second alternation was preceded by a student movement that turned into arising social protest in Mexico. As the presidential campaign began, the candidate of the coalition Compromiso por México, composed of the Institutional Revolutionary Party and the Green Ecologist Party of Mexico (PRI-PVEM), Enrique Peña Nieto, was harshly questioned by students regarding their relationship with Televisa and TV Azteca. Students called him killer a result that during his time as Governor of the State of Mexico, in which traders were attacked by the police, and had to be defended by the citizens of Atenco, who were also violently repressed [24].

In September 2014, the murder of 43 students from a rural school in Ayotzinapa and the darkening of the facts by the public authority generated a wave of demonstrations against the regime designated as authoritarian. Even to this date, their murder has not been clarified [25].

These events and others put into question to Mexican democracy, a democracy that is supported in rules of the game widely favoring an elite political, but insufficient to guarantee the quality in terms of satisfaction citizen, full respect for the rights that are expanded on the realization of freedom, and progressive expansion of political, social and economic equality.

38 In that decade only Venezuela, Costa Rica and Colombia had continued, and periodic elections backed institutions authoritarian of Brazil, among its strategies, polling that guarantee competitive processes, Chile went through an abrupt change of regime in 73 , which involved the dismissal of Salvador Allende; bureaucratic authoritarianism resorted to the institutional acts to implement exemplary punishments aimed to punish propaganda on radio and television, affecting the balance of the political strife, for example, the 1976 law Falcao. By this to the guarantee is results election to his favor, the PRI was considered an hegemonic party. 


\section{Conclusions}

The Mexican political system has had important transformations that have led to the consolidation of a democracy representative, but have not achieved a democracy of quality. Thus, although since 1997 each election is characterized by partisans' competitive level, which is normally an indicator of healthy democracies, and although in the last reform, after many decades the independent candidates returned to the competition for power, many of the practices inherited from the hegemonic PRI are still present. For decades this party was the axis of the Mexican political system, which partly explains why the alternation in 2000 did not mean, as many had predicted, the fall of this party's power. On the contrary, its power has persisted. Despite the fact that it has led to a non-competitive system ${ }^{39}$ [26], it is actually undeniable that this party still has strength within the Republic Presidency.

PAN's initiative to create the National Electoral Institute in order to centralize the Organization's local and federal elections actually involved only a change of name and some faculties of this organism in the field of local elections. But with two electoral processes to test (2015 and 2016), reality shows that elite turned to reform as a strategy to legitimize themselves, setting the re-election, the parity of gender, independent candidates and other aspects, without aiming to obtain the quality needed in democracy.

Therefore, each reform ends up being just a small step to strengthen representative democracy. As for a reform of the State, even if it is a fundamental need to create conditions that have an impact on the quality of democracy, it is not currently a target of political actors, which explain the constant social mobilizations that started from the campaign of the President who starred in the second alternation.

\section{REFERENCES}

[1] Schumpeter, Joseph, Dos conceptos de democracia, en Quinton, Anthony, Filosofia Politica, Fondo de Cultura Económica, Breviarios número 239, México, 1974.

[2] Almond, G. y Verba Sidney, The Civic Culture, Political attitudes and democracy in five nations, Princenton University, Press, 1963.

[3] Przeworski, Adam, Democracia y mercado, Alianza Universidad, Madrid, España, 1996.

[4] Duverger, Maurice, Ley constitucional e instituciones politicas, Editorial Ariel, Mexico, 1992.

39 In the last two decades of the 20th century many even raised the disappearance of the PRI in the short term, there are people who placed the date of the twilight of that party in 2029 .
[5] Huntington, Samuel, The third wave, democratization at the end of the 20th century, Paidós, 1994.

[6] Morlino, Leonardo, Democracia y democratizaciones, Ediciones CEPCOM, México, 2005.

[7] Easton, David, Esquema para el análisis político, Amorrortu editores, Buenos Aires, Argentina, 1969.

[8] Luhmann, Niklas, Organización y decisión, autopoiesis, acción y entendimiento comunicativo, Editorial Anthropos y Universidad Iberoamericana, España, 1997.

[9] Peter A. y Taylor, Rosemary C. R., Political Science and the three new institutionalisms, en Political Studies 1996 number XLIV.

[10] Duverger, Maurice Los partidos políticos, Fondo de Cultura Económica, México, 1996.

[11] Nohlen, Dieter, Sistemas Electorales y Partidos Políticos, Fondo de Cultura Económica, México, 2005.

[12] González Casanova, Pablo, El Estado y los Partidos Políticos en México, Ediciones Era.

[13] Article 35 of the Political Constitution of the Mexican United States.

[14] Woldenberg, José, Et. al., La mecánica del cambio político en México, Cal y Arena, México, 2000.

[15] Bulnes, Francisco, Et. Al., Sucesiones, destapes y elecciones presidenciales, Tomo I, El Universal, México, 1994.

[16] Del Río, Salvador, Presidentes de México, Fondo de Cultura Económica, México, 1990.

[17] Coutiño, Fabiola, Estudio de Derecho Electoral Mexicano, editorial Limusa, México, 2011.

[18] Sartori, Giovanni, Partidos y sistemas de partidos, Alianza editorial, Madrid, 1980.

[19] Cosío Villegas, Daniel, El Sistema Político Mexicano, las posibilidades de cambio, Cuadernos de Joaquín Mortiz, México 1973.

[20] Molinar Horcasitas, Juan, El tiempo de la legitimidad, editorial Cal y Arena, México, 1991.

[21] O'Donell, Schmitter, Whitehead, Transiciones desde un gobierno autoritario, Tomo I, perspectivas comparadas, Paidós, España, 1994.

[22] Dahl, Robert, El dilema del pluralismo democrático, Alianza editorial, México, 1994.

[23] Nohlen, Dieter, Institutions and political culture, in studies Journal of politics and society, New Era, volume 1, number 1, January-April 2008

[24] http://eleconomista.com.mx/columnas/columna-especial-p olitica/2012/05/21/pena-nieto-atenco"2/05/21/pena-nieto-a tenco. Consulted in august 30th, 2013.

[25] http://www.jornada.unam.mx/ultimas/cobertura-al-minutoayotzinapa-a-un-ano-la-herida-sigue-abierta

[26] Pinchetti, José Agustín, La Democracia que viene, Ed. Grijalbo, México. 